\title{
Students’ Activity Involvement for Speaking Ability Improvement
}

\author{
Fitrotul Mufaridah \\ mufaridah@unmuhjember.ac.id \\ Universitas Muhammadiyah Jember
}

\begin{abstract}
To make students' ideas become real, it needs act that can make them bring themselves to explore what is in their mind. The action done by students in the classroom would encourage them to be able to be creative in speaking class. The creativity should be facilitated by the teacher by providing more rooms for the students to involve much in the classroom activities. It is more meaningful for the teacher to design the classroom activities by involving students' participation. The design should facilitate both teacher and students to practice the teaching and learning activities creatively, so the class would be more interesting and more authentic. The students' involvement can also empower the student-teacher relationship and bridge them to minimize gap. In the process of having speaking classroom activities, the teacher can learn more on how to listen to students' ideas and how to appreciate them respectfully to their creativity. The teachers can build the students' creativity and guide them how to implement it well for students' learning experience. In another side, the students are invited to explore their smart ideas in developing learning experience which is leading them to do creative and meaningful learning activities. They come to class not only as the passive participants of the learning activities but also as the active participants in proposing and acting their ideas in speaking class. It is really challenging involvement for the students. It brings them to have bigger responsibility in doing learning process. So, the students' activity involvement are experienced them to enrich their creativity and to enhance their speaking ability.
\end{abstract}

Keywords: classroom activity design, learning experience, meaningful learning, challenging involvement, creativity enrichment.

\section{INTRODUCTION}

The objective of English teaching as a foreign language is to enable the students to develop communicative competence in four language skills, as stated in the main objective of lecturing at some English subjects. Particularly, the objective of speaking ability is to develop a basic of that skill in English which would enable graduated students to apply effectively in their real life situation. But in the process of teaching and learning English, students commonly face a lot of problem with speaking ability up to now. The informal dialogue (interview) that was done by the researcher and the teachers discovered that the teachers' chance to give the students individually attention when the teaching learning process happens was insufficient. This happened because there is no design of teaching which is appropriate for answering students' need. It is also sometimes because of the students' number in one class was too big. The teacher could only ask some students to practice. So, this situation could make the class not conducive. In facts, students' speaking ability are still less in their learning English because they are not having teaching and learning design which is able to formulate them to practice and share more about the subject.

Those influencing problems can be predicted as the cause of un-effective teaching and learning in English speaking class. Meanwhile, speaking classroom always needs many language and mental requirement. It is supported by Brown \& Yule (1983: 17) that learning to talk foreign language is often considered to be one of difficult aspects of language learning by the teacher to help the students. This declared that teaching speaking is not always easy by doing a particular practice. It needs more and more ways to improve it.

For better implementation, it should be found the solution to enhance the students' English speaking ability. Teacher should invite students to be involved not only in the process of teaching and learning, but also in the process of designing the teaching and learning will be 
done in the English speaking class. Positioning students to be partner in designing the teaching and learning activities would make them as the source or manager in our class or subject. It is in line with Streeting and wise, 20019:2 cited in Heally, Flint, and Harrington, 2014:22) statement that:

"Students as 'co-producers', not as 'consumers' ... are viewed as essential partners in the production of the knowledge and skills that form the intended learning outcomes of their programs. They are therefore given responsibility for some of the work involved, and are not passive recipients of a service".

The partnership of students and teacher would enhance the students' ability with full of responsibility and accurately because they do all the activities and communicate much with the teacher directly. The teacher also could do observation and record of the students' progress authentically.

The work of designing together between the students and the teacher would open the gap between them. The communication facilitate them to start in breaking down the information gap and discussion quality gap, so they would be really possible to share their needs, ideas, experiences, and some other else. The breaking of the gap could motivate and develop the students to believe more in their ability and quality.

The ability and quality the students could improve are about personal communication, participation, analysis, and also decision making. It is supported by Cook-Sather, Bovill, Felten (2014: 6-7, cited in Heally, Flint, and Harrington, 2014:22) that:

"We define student-faculty partnership as a collaborative, reciprocal process through which all participants have the opportunity to contribute equally, although not necessarily in the same ways, to curricular or pedagogical conceptualization, decision-making, implementation, investigation, or analysis".

The partnership could give advantages to the success of teaching and learning process and result. The partnership also brought the students to the real development of personality and academic. Partnership also made the teacher to listen more to the students' need and idea. The teacher could improve her or his creativity inspired by the students' sharing and opinion. Partnership could enlarge teacher's ability in combining students' idea in designing the teaching and learning activities.

Partnership even could bring both of the students and the teacher to create models in teaching and learning activity. The model for students as partners in simple distinction may be made between a focus of students as partners on:

a) student engagement in learning, teaching and research;

b) student engagement in the quality enhancement of learning and teaching practice and policy (Heally, Flint, and Harrington, 2014:23) .

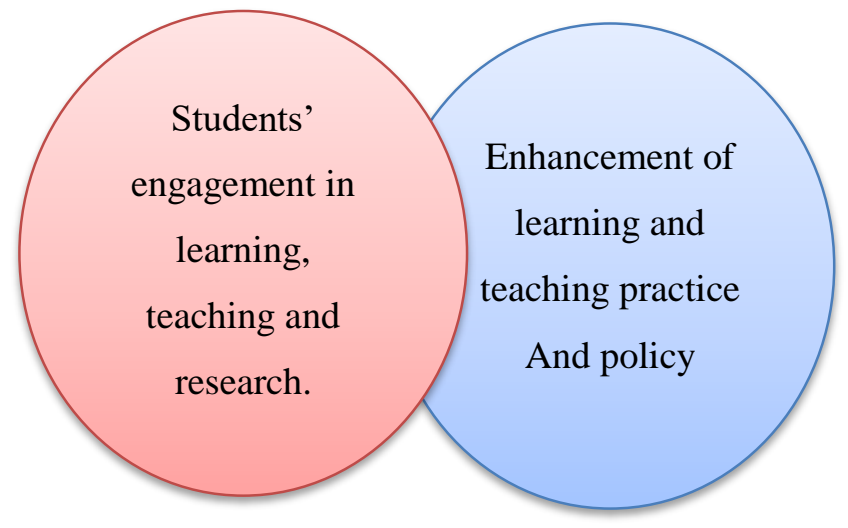

Figure 2.1: Simple model of students as partners

The model becomes the result of potential partnership between the teacher and the student. So, doing partnership in designing the class activities is alternatively important to do for improving the quality of teaching and learning process, especially for students' speaking 
ability improvement. The model resulted from the student-teacher design could be the inspiring process in handling the class.

\section{METHOD}

This research was qualitative research in classroom action research. Classroom action research is defined as the study of a social situation with a view to improving the quality of action within it (Elliot, 1991: 69). This research is to find an alternative solution to improve the quality of action done in the classroom. The quality of the action focused on the designing English class activities.

The action of this research was conducted by using the cycle model which consists of four stages of activities, they are (1) Planning, (2) Acting, (3) Observing, (4) Reflecting. This research design has explained by Arikunto (2006: 92) that action research occurs in dynamic and complementary process which consists of four essential moments of planning, action, observation, and reflection. The moments are basic steps to undertake the function of each: developing a plan of critically informed action to improve what is already happening; acting is to implement the plan; observe the effects of critically informed action in the context in which it occurs; and reflecting on these effects is as the basis for further planning, subsequent critically informed action and so on through succession stages. The design of this action research is illustrated in the following diagram.
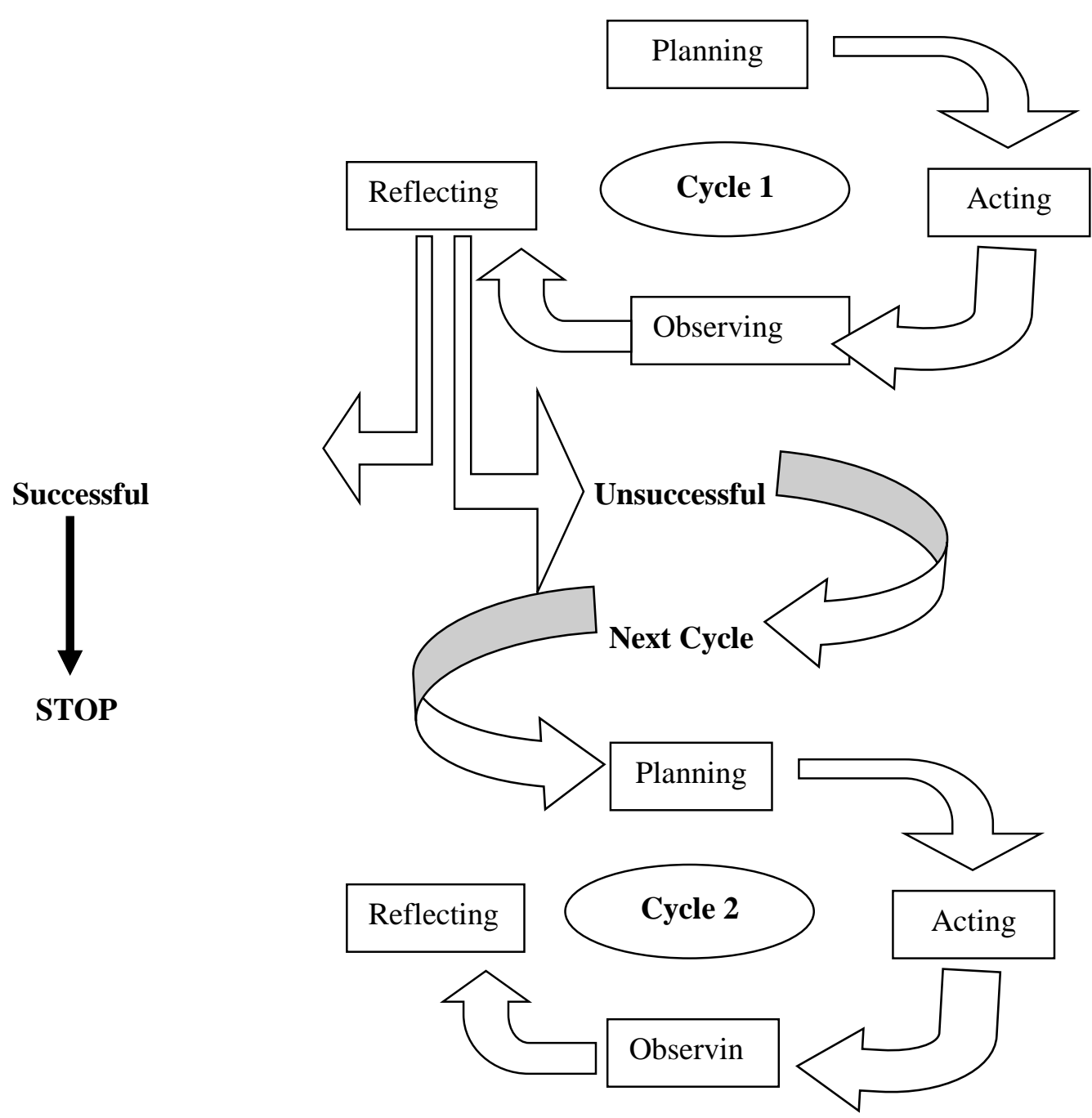
Figure 1. The design of classroom action research (Arikunto, 2006: 91)

For limiting the research, it was taken the fourth semester of English Language Education Program of University of Muhammadiyah Jember as the subject of the research. There are 29 students as the subject of the research.

For acquiring the research data, the observation was done. The performance test was also given to the students. The data was taken in every meeting in the observing step. The data analysis then was functioned as the reflecting of the action. The reflecting result decided to stop or to continue the action to find another in the next cycle. The research result become focus material to be discussed. The discussion would bring to the conclusion as the finding of the research.

\section{RESULT AND ANALYSIS}

Designing speaking class activities which openly invite the students to involve much was really challenging for the students to participate more and more not only in the process of teaching and learning activities, but also in the process of designing the planning of teaching and learning activities done in speaking class. In this work of designing together between teacher and students, students could explore more not only the idea of designing appropriate activities suitable for them, but also about their speaking abilities. The work of designing together was always done through English communication. It was of course, making the students easier to use English in their communication.

After implementing the design, the result of observation in the first cycle showed that 15 of $29(51.7 \%)$ students were active during the teaching learning process of speaking class in the first meeting. In the second meeting, there were 17 of 29 (58.6\%) students were active during the teaching learning process of speaking class. In the third meeting, there were 19 of $29(65.5 \%)$ students were active during the teaching learning process of speaking class

For the better involvement results in second cycle, there were 22 of $29(75.8 \%)$ students were active during the teaching learning process of speaking class in the first cycle. Next, there were 25 of $29(86.2 \%)$ students were active during the teaching learning process of speaking class in the second cycle. Meanwhile, the result of the students' speaking ability in the first cycle showed that the students' average score were 75 . In second cycle, the average score were 81 . This result was reflected that individual involvement in speaking class design provided the students to be encouraged to explore their ideas, easy to be more creative, and facilitated to practice English better. The students are creatively shared their minds with their friends and teacher in small group for improving speaking ability.

In the first cycle, the result of observation and performance test showed that the students' involvement process in speaking activities design did not run well yet. The students' were not openly yet to share their ideas of speaking activities and they were not creative to perform their speaking practices. There were found some problems considered as the cause of the unsuccessful result in cycle I. They are explained below.

1. Some students are still passive without giving any idea in designing the activities, even in the process of the activities. They seem like confused to follow the activities because some of their friends dominated the activities.

2. The process of designing the activities are not focused because classical ideas. The ideas are taken from one by one student. It made the students feel unconfident, and it influenced the students' attention and motivation.

3. The teacher was not focusing on one specific idea, but general idea. It was predicted that the students did not practice optimally because the teacher had already tried to accommodate the general idea.

Those problems can be predicted as the cause of the research result in cycle I. This is but a common problem in speaking classroom. Speaking classroom always needs many language and mental requirement. It is supported by Brown \& Yule (1983: 17) that learning to talk foreign language is often considered to be one of difficult aspects of language learning 
by the teacher to help the students. This declared that teaching speaking is not always easy by doing a particular practice, it needs more and more practices.

For better implementation, some revised actions to open more for students to participate were by giving them wider possibility to take part of the activities. By taking an interest in doing the learning activities in the classroom, the students would be more enthusiast in practicing their speaking performance. It was also what Astin (1999) explained that personal development gathered in any educational program could be happening through proportional quality and quantity involvement in the program. So, that is why the revised actions have done in cycle II. The actions have been done with certain reason of teaching and learning English through student-teacher partner design. They are as in the following explanation.

1. The first was doing the design through the small group, so each student had opportunity to contribute their ideas. It was not dominated by some students only. Small group discussion could facilitate every student to exchange their idea among them. Within a group, chance errors among members can be corrected. Group discussion often stimulates ideas that might not occur to the individual working alone (Johnson and Johnson: 91). And this action actually helped the students much in speaking English better.

2. The second was by doing grouping which consist of not more than five students, and then making a simple discussion in designing the teaching and learning activities for the next class by specific topic of material. This action was hopefully able to give the students to decide which design could give more learning experiences, not only giving the idea of teaching and learning activities appropriate to their need, but also giving them more chance to practice their English communication with their friend and also their teacher. So, they can provide suitable activities to heir need. This belief is supported byJohnson and Johnson (1982: 91) that "the quality of decision making in such situation depends on the processes of information exchange".

The better result of making decision in designing the teaching and learning process are from small group discussion. The idea the students gave are more valid and appropriate.

3. The third is by using more creative combination. The teacher should be able to accommodate the vary ideas within the group. The teacher creativity in combining the students' ideas is properly tested here. Some other media are possible to use, like picture to practice, so the students could learn and play with the partner by showing the picture to another. This action supported by Scott and Ytreberg (1990:3) that actually young children love to play, and they will learn best when they can enjoy themselves in their learning activities. In fact, this action contributed much to the students' speaking ability, because they could learn seriously and nicely with the implemented action.

The implementation of Students' involvement in designing speaking activities in the second cycle could bring the result of students' active participation to be 25 of 29 (86.2\%) students from 15 of $29(51.7 \%)$ students in the first meeting of first cycle. Meanwhile, the result of the students' speaking ability was improved to be 81 as the average score in the second cycle from average score 75 in the first cycle.

Furthermore, Johnson and Johnson (1982: 92) explained that when the students working in a group, they are also allowed to imitate the action of more highly motivated member. The drills convey the students to do English routines practices, and therefore of course, it makes them be easier in using English in their English communication practices. It is also strengthened by Brown and Yule (1983: 5) that speaker knows every single word which passes his lips will be heard by his listener, and if they are not in what he intends, he will take active revision in the communication. This means that by spelling and pronunciation drills, and also followed by practicing in making sentences will help the students to know and become more aware of what they are saying about, so when they find some problems in their communication, they can easily revise the matter of their speaking. 


\section{CONCLUSIONS AND SUGGESTION}

The reflection of the research showed that the idea of the students on what they need to do in the process of teaching and learning can be designed properly and appropriately because it was based on the students' need. the quality of challenging involvement for the students to design speaking activities encourage them to be easier in sharing their ideas, be more responsible in doing learning process, and be more creative in performing their speaking. Grouping model were also better solution to enhance their speaking ability. Through grouping, the students also could find their real meaningful learning in accommodating and combining their speaking ideas. So then, it can be concluded that students' involvement could enrich the students' creativity, and enhance their speaking ability optimally.

\section{REFERENCES}

Arikunto, S. (2006). Prosedur Penelitian: Suatu Pendekaan Praktik. Jakarta: Rineka Cipta

Brown, G.,Yule, G. (1983). Discourse Analysis. Cambridge: Cambridge University Press.

Brown, G.,Yule, G. 1999. Teaching The Spoken Language. Cambridge: Cambridge University Press.

Elliot, J. 1991. Action Research for Educational Change. London: Open University Press.

Healey, M, Flint, A, and Harrington, K. (2014). Engagement through Partnership: Students as Partners in Learning and Teaching in Higher Education. Yorkshire: Higher Education Academy.

Johnson, David W. and Johnson, Frank P. 1982. Joining Together, Group Theory and Group Skills. London: Prentice -Hall, Inc.

Astin, Alexander W. Student Involvement: A Developmental Theory for Higher Education. Journal of College Student Development, 40(5): 519 Retrieved from https://www.middlesex.mass.edu/ace/downloads/astininv.pdf in September, 14 ${ }^{\text {th }}$, 2017 at $05.37 \mathrm{am}$. 